\title{
Por entre rendas, jóias e perfumes de jasmim: a moda segundo Eça de Queirós
}

\author{
Monica Figueiredo \\ (Universidade Federal do Rio de Janeiro)
}

\section{RESUMO}

A partir da leitura de Os Maias, pretende-se analisar as imagens criadas pelo discurso ficcional de Eça de Queirós, partindo da concepção barthesiana de que todo o gvestuário escrito h é construído em vista a uma significação. Neste romance, as roupas e seus adereços inscrevem um discurso crítico que reavalia as relações sociais, históricas, e subjetivas experimentadas pela realidade oitocentista.

PALAVRAS-CHAVE: Eça de Queirós, Literatura Portuguesa Oitocentista, Moda

\section{ABSTRACT}

From reading of The Maias, we intend to analyze images that have been created by the fictional discourse of Eça de Queirós, based on the barthesian concept that all "written clothing" is built in view of a signification. In this romance, clothes and its garment subscribe a critical discourse that reconsiders social, historical, and psychological relationships experienced by the reality of nineteenth-century.

KEYWORDS: Eça de Queirós, Nineteenth-century Portuguese Literature, Fashion 
Ah! se já perdermos a noção da hora

Se juntos já jogamos tudo fora

Me conta agora como hei de partir (...)

Como, se na desordem do armário embutido Teu paletó enlaça o meu vestido

E o teu sapato inda pisa no meu

Como, se nos amamos feitos dois pagãos

Meus seios inda estão nas tuas mãos

Me explica com que cara eu vou sair (...)

(Eu te amo. Chico Buarque de Holanda)

Quando os livros se tornam objetos de amor, o necessário distanciamento crítico exigido pela leitura acadêmica tende a ser preterido em favor do exercício de um prazer que não se cansa de percorrer as mesmas páginas em busca daquilo que já se conhece e que, não raras vezes, nos surpreende ao ser capaz de apontar para a existência dum outro tanto que até ali havia passado despercebido: reler é atualizar um gozo já vivido e constatar que os livros nunca deixam de ser inéditos.

A verdade é que quando gostamos de um livro, firmamos um estranho contrato de fidelidade que muitas vezes impede que nossos olhos busquem por outros casos de amor. Reconheço que é esta a minha relação com Os Maias de Eça de Queirós. Publicado em 1888, depois de longa e tumultuada gestação, o livro é considerado pela crítica queirosiana a obra-prima de Eça, funcionando como marco da virada na produção de um autor que, supostamente livre e desimpedido das exigências da escola naturalista, encontraria a maturidade de sua escrita. Mesmo duvidando da existência de dois eças por motivos que não caberiam no espaço deste texto, creio que Os Maias são um livro inesquecível, não só pela presença de um enredo que extrapola qualquer intenção meramente programática - não se pode esquecer de que o romance foi primeiramente projetado como parte integrante das "Cenas da Vida Portuguesa" -, mas também pelo caráter inovador que a linguagem estética adquire ao longo das mais de setecentas páginas que compõem a monumental "pintura a fresco" ${ }^{11}$ planeada por seu autor. Ademais, ler Os Maias é experimentar uma excursão por emoções que, trágicas, cômicas ou simplesmente banais, recuperam a precariedade da condição humana.

Desta vez, o que me fez retornar à história da família Maia foi um outro livro, o de Gilda de Mello e Souza, O espírito das roupas. A moda no século dezenove, presenteado por uma amiga que como eu tem os olhos voltados para os tempos da Rainha Vitória. O texto, claríssimo desde seu título, faz uma recuperação da história do traje na era vitoriana, mostrando que a evolução da moda oitocentista foi fortemente motivada pelas profundas alterações sociais, econômicas, políticas e históricas vividas no Ocidente pela aburguesada sociedade do século XIX. Se por um lado, em seus primórdios, o surgimento da roupa pode ser 
parcialmente explicado por razões de pudor, ou por motivos ligados à sobrevivência humana², por outro, não se pode duvidar de que foi como veículo de distinção de classes e de exibição de poder que a roupa deixou de ser meramente um abrigo para o corpo, ou uma resposta à suposta vergonha humana para se tornar um complexo sistema que atende pelo nome de moda.

Com efeito, ao mesmo tempo em que traduz a necessidade do adorno, a moda corresponde ao desejo de distinção. A maior parte das leis suntuárias atestam a intenção, entre os reis que a editavam, de manter as distinções de classe sobre as quais a sociedade repousava. (SOUZA, 2005, p. 47).

O desenvolvimento técnico-industrial e o aumento avassalador da produção alteraram as condições de vida de milhões de indivíduos que começaram a ser chamados de consumidores. A partir dos oitocentos, ser um consumidor torna-se sintoma da cidadania vivida dentro de uma realidade altamente competitiva, mecanizada e produtiva; por outras palavras, o poder aquisitivo determina, a partir de então, o lugar de cada indivíduo na pirâmide social. Se compararmos o consumo do século burguês com aquele experimentado durante o Antigo Regime, perceberemos que até o século XVIII as relações estabelecidas entre o mercado consumidor e o volume de produção estavam baseadas "numa vinculação dissimétrica: só se podia consumir o que era produzido, mas a transformação dos bens precedia a demanda" (ROCHE, 2000, p. 25).

O século XIX experimentará uma série incontável de revoluções que alterarão as relações dos grupos sociais, bem como abalarão a própria relação do indivíduo consigo mesmo, fazendo com que "o choque do novo" se torne "uma assinatura da época". Mais do que serem apenas um fenômeno social, as mudanças sofridas pela realidade oitocentista também modificaram o panorama cultural existente, pois "as artes, a música e a literatura mostraram-se igualmente voláteis" (GAY, 2001, p. 16), originando o surgimento de toda uma produção- logo vista como mercadoria rentável - que apostava no refinamento do gosto, no controle das emoções e na valorização das ditas boas maneiras. É neste esforço de contenção + cortesia que a moda ajudará aos burgueses a firmarem para si uma imagem que o século XXI ainda não conseguiu ultrapassar. A invenção da máquina de costura ${ }^{3}$, a criação dos primeiros catálogos de moda, o surgimento da figura do estilista, as lojas de departamentos ${ }^{4} \mathrm{e}$ os popularíssimos manuais de boas-maneiras são modificações que fazem com que a roupa e seus adereços se tornem cada vez mais um bemao alcance de muitos, ao mesmo tempo em que cria a dependência do indivíduo com a sua aparência:

A moda, entre liberdade e sujeição, se presta a todos os jogos da distinção, do poder. Podemos considerar a vestimenta em primeiro lugar entre os agentes da "civilização dos costumes" e da "civilização de corte", mas sempre levando em conta o laço profundo que se cria entre o mundo e o indivíduo. É o que ensina Denis 
Diderot (...): o traje é a expressão do ser, qualquer mudança de traje induz transformações da pessoa, das coisas que a cercam. (ROCHE, 2000, pp. 13-14)

É através da relação do homem com os objetos que a história também se inscreve, pois o consumo, mais do que uma forma exclusiva de alienação - como quiseram crer os marxistas da primeira hora ou os mais arrivistas -, não deixa de ser uma "maneira de reconciliar o sujeito com o objeto, a interioridade com a exterioridade" (ROCHE, 2000, p. 16), afinal qualquer objeto "contém engenhosidade, escolhas, uma cultura" e, portanto, não pode ser visto apenas como local de nossa alienação, mas antes o "meio de um processo criativo" (ROCHE, 2000, p. 19) que aponta para a relação do indivíduo com o social. O trabalho dos Annales já havia demonstrado - desde o início dos anos trinta ${ }^{5}$-, o quanto o cotidiano e sua materialidade podem ser campo fértil para a inscrição da passagem do tempo, servindo de palco para a demanda estabelecida entre o homem e a sua realidade. A história das mentalidades, quando promoveu os estudos que "requestionaram as certezas relacionadas à eficácia do modelo do homo aeconomicus para compreender as sociedades antigas" (ROCHE, 2000, p. 16), paradoxalmente, acabou por também ajudar a entender a obsessão pela imagem, a ditadura da beleza corporal $^{6}$ e a sofreguidão da moda decorrentes do sucesso econômico que as roupas e seus artefatos foram capazes de gerar nestes últimos três séculos. Assim, a economia da roupa cedo se pautou em duas certezas simultâneas:

(...) da economia estacionária, cujas aparências e regras estavam fixadas pelas situações sociais - o hábito faz o monge, cada um deve consumir segundo sua classe, argumento central das civilidades desde Erasmo -; (...) da economia do luxo, em que os práticos e os exegetas da moda exaltam o desejo de se distinguir dos grupos inferiores - daí a comercialização das necessidades e a construção de novas identidades sociais para o indivíduo. (ROCHE, 2000, p. 32)

O século XIX incluirá a moda no cerne do debate econômico, uma vez que ela foi capaz de alterar os valores da "economia cristã e estacionária, porque iniciou a economia da circulação, da mudança pessoal e do individualismo" (Roche, 2000, p. 331). No afã de se tornarem burgueses, os pequenos da classe média insistiam na sua distinção do proletariado esfarrapado e mal vestido. Por isso, copiar o vestuário da burguesia mais abastada era uma forma de deixar claro aquilo que não se queria ser. Os burgueses estabelecidos viam nos seus trajes sóbrios e negros um reflexo da seriedade desejada para a sua condição social, ao mesmo tempo em que apostavam na menos discreta vestimenta de suas mulheres que - imobilizadas por anáguas, espartilhos e crinolinas comprovavam o quanto o ócio era uma prerrogativa privilegiada de sua classe social. Quando comparado a outros períodos históricos, o século XIX alimentou a ganância feminina - usada como metáfora do sucesso masculino -, ao fazer as mulheres desejarem um número maior de trajes que "representavam a situação econômica e social de quem as vestia, [as 
roupas] eram dispendiosas e, portanto, possuí-las em quantidade era sinal de riqueza" (SCHMITT, 2010, p. 100). Os exageros que sempre marcaram a roupa dos poderosos - e não foi diferente na época vitoriana - estiveram a serviço de um significado preciso, pois as mangas imobilizantes, as caudas longuíssimas, os espartilhos sufocantes, a amplidão das saias, as unhas compridas, os saltos altos, as luvas excessivamente apertadas, enfim, toda roupa com peso e com tamanho desmedidos mostrava a quem quisesse ver, através do visível desconforto, que aquele que a trajava estava de fato afastado de qualquer forma de trabalho produtivo, pertencendo com isso à classe privilegiada, porque condenadamente ociosa. Parece claro, portanto que:

O vestuário fala[sse] de muitas coisas ao mesmo tempo, seja em si próprio, seja por um detalhe. Ele tinha uma função de comunicação, pois por ele passava a relação de cada um com a comunidade. $O$ traje revelava primeiro a vinculação a um sexo, a uma comunidade, à idade, a um estado, a uma profissão, a uma posição social. Essa linguagem geral devia ser compreendida por todos, apesar de suas variações segundo o nível de fortuna, dos modos de vida, do avanço da idade, da evolução da mobilidade social das famílias. (ROCHE, 2000, p. 258)

A "vestimenta é uma linguagem simbólica, um estratagema de que o homem sempre se serviu para tornar inteligível uma série de idéias" (SOUZA, 2005, p. 125), por isso, a roupa desde cedo ultrapassou as funções primárias de proteção ou de pudor. A era vitoriana fez da moda um sistema de significação que "aprendeu a jogar com todas as possibilidades da linguagem para acelerar o consumo" (ROCHE, 2000, p. 257), acarretando para o futuro das sociedades burguesas a mitificação de um discurso que naturalizou, tornou razãoe que esvazioua diversidade dos sentidos daquilo que antes poderia ser compreendido de variada maneira. A moda no mundo burguês torna-se um mito, fala despolitizada assentada numa razão absoluta que impede o salutar confronto de sentidos:

É possível completar agora a definição semiológica do mito na sociedade burguesa: o mito é uma fala despolitizada. O mito não nega as coisas; a sua função é, pelo contrário, falar delas; simplesmente, purifica-as, inocenta-as fundamenta-as em natureza e em eternidade, dá-lhes uma clareza, não de explicação, mas de constatação: se constato a imperialidade francesa sem explicá-la, pouco falta para que se ache normal, decorrente da natureza das coisas. fico tranqüilo. (...) O mito organiza um mundo sem contradições, porque sem profundeza, um mundo plano que se ostenta em sua evidência, cria uma clareza feliz: as coisas parecem significar sozinhas, por elas próprias. (BARTHES, 1993, pp. 163-164) 
Mesmo sabendo que o discurso barthesiano se reinventou e não esquecendo de que muitos de seus textos devem ser lidos hoje à luz do momento histórico que os produziu, pego de empréstimo os conceitos de Roland Barthes para analisar as relações estabelecidas entre o mundo burguês e aquilo que o autor de Mitologias chamou de o "sistema da moda". Barthes acreditava que a burguesia foi capaz de construir para si uma representação, ou antes, uma imagem que se firmou como universal porque se ergueu sob os progressos técnicos e científicos que propiciaram uma transformação ilimitada da natureza. A natureza "transformada" cimentou-se como razão, abrindo espaço para uma forma de percepção precária que iria apostar na máxima "assim é porque deve ser", ou por outras palavras, "a ideologia burguesa é cientista ou intuitiva, constata o fato ou reconhece o valor, mas recusa a explicação: a ordem do mundo é suficiente ou inefável, nunca significativa" (BARTHES, 1993, p. 162). Assim, numa sociedade aburguesada e marcada por um forte apelo ao consumo, o real estaria encoberto por um acúmulo de imagens que procurariam obliterar a visão dos "espectadores" que, condicionados, olhariam para o espetáculo da vida através de densa cortina de imagens ideológicas prontas, indiscutíveis e fortemente sedimentadas:

Para obnubilar a consciência contável do comprador, é necessário estender diante do objeto um véu de imagens, de razões de sentidos, elaborar em seu redor uma substância mediata, de ordem aperitiva, em suma, criar um simulacro do objeto real, substituindo o tempo pesado do desgaste por um tempo soberano, com a liberdade de se destruir a si mesmo por uma ato de potlachanual. (BARTHES, 1979, p. XXII)

Barthes ao analisar jornais, revistas, suplementos de moda, catálogos dos grandes magazines, enfim ao se debruçar sobre as formas que propagandeavam todo um arsenal de produtos destinados a "vestir" a burguesia contemporânea, define que o "sistema da moda" é formado por três possibilidades representação do vestuário: o "vestuário real", o objeto a ser recriado por imagens ou por palavras; o "vestuário imagem" - as fotografias e os desenhos usados pelas publicações de moda -, e o "vestuário escrito" que tem na língua e em sua capacidade descritiva o instrumento de realização. O "vestuário real" está abarcado "de finalidades práticas: proteção, pudor, adorno", fins que estão apartados dos vestuários representados pelas imagens ou pelo discurso. Se o "vestuário imagem" pode ainda significar proteção, pudor, adorno, "o vestuário escrito não tem nenhuma função prática nem estética: ele é todo constituído em vista de uma significação" (BARTHES, 1979, p. 8). A linguagem que dá forma ao "vestuário escrito" não tem por intenção primeira a cópia do real, antes, usando e abusando da descontinuidade e da fragmentação, a descrição da moda quer "sobretudo difundir largamente a moda como um sentido" (BARTHES, 1979, p. 9). Roland Barthes propõe então uma aproximação inevitável:

Moda e literatura dispõem, efetivamente, duma técnica comum cujo fim é parecer transformar um objeto em linguagem: é a descrição. (...) Em literatura, a descrição 
se apóia num objeto oculto, real ou imaginário: ela deve fazê-lo existir. Em moda, o objeto descrito é atualizado, dado à parte sob sua forma plástica, senão real, pois que só se trata duma fotografia. (BARTHES, 1979, p. 12)

Não se pode afirmar que Eça de Queirós, ao descrever o imenso guarda-roupa que se desdobra ao longo das páginas de Os Maias, partia de objetos reais ou, ao contrário, usando a imaginação, as suas descrições acabaram por realizar todo o figurino que a narrativa insistentemente explora. O que aqui de perto me interessa é analisar a importância que as roupas desempenham dentro do romance, atuando de forma decisiva na construção do enredo. Negando a condição do detalhe, ultrapassando a função meramente cênica, escapando da condição de índice, creio que o "vestuário escrito" criado por Eça de Queirós deseja (e repito com Barthes), "sobretudo difundir largamente a moda como um sentido"

Obviamente, Eça era um escritor burguês que escrevia para um público burguês, em pleno século XIX, e como os mais importantes autores seus contemporâneos, não tinha nenhum apreço à classe a que pertencia. Seus livros não pouparam linhas para atacar a burguesia portuguesa, fosse ela precariamente interiorana ou herdeira de um passado de fidalguia. Intuindo aquilo que Barthes depois conceituaria, Eça não duvidou do poder de sedimentação que a ideologia burguesa era capaz efetivar, de modo que encaminhou a sua ficção na direção da desconstrução da naturalização dos valores burgueses, por acreditar que o discurso literário poderia intervir criticamente na realidade referencialmente histórica a que pertencia. Como Barthes, o autor de $O$ crime do padre Amaro sempre soube que a literatura é o "logro" salutar que liberta o discurso de seu "fascismo" inerente". Ao compor a sua "pintura a fresco", Eça fez de Os Maiasum instrumento estético destinado a desestabilizar as certezas burguesas que compõem os valores, ou melhor, a ideologia que dá corpo à realidade ficcional em que estão inclusas as suas personagens. Das roupas à descrição das ruas de Lisboa, o que o leitor tem diante de si é um discurso corrosivo que denuncia a difícil tarefa de se manter vivo diante de um mundo em dissolução.

Eça de Queirós sabia que a roupa foi para sociedade vitoriana uma espécie de investiduraque qualificava aqueles que não desfrutavam do antigo direito de nascimento, mas antes competiam ferozmente para sobressaírem numa realidade em que cada um agora era o que tinha. é no século XIX, quando a democracia acaba de anular os privilégios de sangue, "que a moda se espalha por todas as camadas e a competição, ferindo-se a todos os momentos, na rua, no passeio, nas visitas, nas estações de água, acelera a variação dos estilos, que mudam em espaços de tempo cada vez mais breves" (SOUZA, 2005, pp. 20-21).

A roupa caminhou a passos largos ao longo dos oitocentos. Aqueles que assistiram à simplicidade dos trajes femininos do início do século (simplicidade de perto alimentada pelas ideias revolucionárias oriundas do século XVIII, que recusou o exagero de herança aristocrática ao abolir os espartilhos, as anáguas, os saltos altos em favor da camisola branca atada debaixo dos seios, essencialmente escassa de adereços e sem formas), não acreditariam que a partir de 1890 as mangas seriam realçadas em contraste à cintura fina, compondo "uma variação nova da 
silhueta tubular, agora colante, transformando a mulher num milagre de curvas" (SOUZA, 2005, p. 64). Durante o período da Restauração Francesa na década de trinta, a anterior simplicidade do início do século é substituída pelas "primeiras mangas baseadas no gibão isabelino e as saias encurtam, armando-se à altura da barra através das anáguas que ressurgem" (SOUZA, 2005, p. 61). Nos anos quarenta, outras modificações serão sentidas, "os penteados elaborados desaparecem, desaparecem as mangas inchadas, que são substituídas por mangas justas nos ombros e muito largas nos pulsos". No entanto, nada será tão devastador quanto o aparecimento da crinolina: "os meados do século vão presenciar o aparecimento da grande descoberta mecânica da vestimenta: em 1855 surge a crinolina ${ }^{8}$, introduzida pela imperatriz Eugênia e simbolizando o triunfo da nova era de aço" (Souza, 2005, p. 63). Em 1870, vive-se "a idade de ouro dos costureiros", acrescida da grande criação da história da vestimenta, "a invenção recente da máquina de costura [que] possibilita a grande elaboração do traje" (SOUZA, 2005, p. 64). A partir de então, as crinolinas vão cada vez mais perdendo a forma circular, para tomarem o desenho de um semicírculo que concentrará o volume do tecido na região lombar, na altura do quadril.

Se o vestuário feminino passou por idas e vindas, o mesmo não aconteceu com o masculino que se direcionou a uma simplificação que acabou por eliminar qualquer forma de distinção, ou seja, "de meados do século em diante a roupa não tem mais por objetivo destacar o indivíduo, mas fazer com que ele desapareça na multidão" (SOUZA, 2005, p. 64-68). Paulatinamente, a roupa passou a ser usada para polarizar os sexos de forma a torná-los inconciliáveis, imagem interessante que competentemente reafirma a distância que separa os valores masculinos dos femininos no mundo burguês:

Mais do que nas épocas anteriores, [a moda] afastou o grupo masculino do feminino, conferindo a cada um uma forma diferente, um conjunto diverso de tecidos e de cores, restrito para o homem, abundante para a mulher, exilando o primeiro numa existência sombria onde a beleza está ausente, enquanto afoga a segunda em fofos e laçarotes. (SOUZA, 2005, p. 71-72)

Diante de tão profundas e rápidas transformações resta saber como Eça de Queirós vestiusuas personagens. Um recurso que parece ser usado em todo livro é o da apresentação da personagem a partir daquilo que está vestindo. Chama a atenção que mais do que qualquer outro elemento seja a roupa o ponto de partida do narrador que, propositadamente, faz com que cada personagem entre em cena acompanhada de uma minuciosa descrição de seu traje. Muitas vezes a roupa será adjetivada no lugar do sujeito, o que faz com que se mantenha uma contaminação semântica que não permite que se separe aquiloque se veste de quemo veste. Vejamos como exemplo: "(...) Ega esperava, sentado no divã de marroquim, e conversando com um rapaz, baixote, gordo, frisado como um noivo de província, de camélia ao peito e plastrão azul-celeste. 0 Craft conhecia-o; Ega apresentou a Carlos o Sr, Dâmaso Salcede (...)" (/ $\mathrm{d}_{2}$, p. 157). O trecho, recortado ao acaso, faz parte de uma das inúmeras 
descrições que acompanham Dâmaso, ("rapaz de fortuna, filho do velho Silva, o agiota" - QUEIRÓS, s/d 2 , p. 177), personagem criado como uma espécie de contraponto ridículo à herança fidalga de Carlos Eduardo, representante de uma burguesia subitamente enriquecida que vivia a dolorosa condição de ilegitimidade, condenado a ser um simulacro falhado de tudo o que admirava. O desejo supremo de Dâmaso era saber "(se o sr. Maia não fazia segredo) quem era o seu alfaiate" (QUEIRÓS, s/ $d_{2}$, p. 189), de certo por intuir que só exteriormente poderia ousar parecer com o herdeiro de uma antiga e ilustre família portuguesa. Dâmaso é marcado por um exagero que o feminiza, destoando, por suas escolhas ridículas, do cenário negro e comedido que assinalava a distinção nas roupas masculinas: "Mandei fazer para o dia das corridas uma sobrecasaca branca... E vou de véu azul no chapéu" (QUEIRÓS, s/d2, p. 310). Partindo da moda inglesa, importada pelo Portugal vitoriano, James Laver explica:

A figura dominante na vida inglesa era agora o burguês respeitável, que não desejava se exibir, mas simplesmente ter uma aparência distinta tanto no escritório quanto em casa. O que estamos assistindo, de fato nesta época, é ao desaparecimento da extravagância e da cor das roupas masculina, que só retornariam em épocas bem modernas. Todas as roupas vistosas eram consideradas deselegantes. (LAVER, 1996, p. 169)

Resta a Dâmaso a rejeição social de que é vítima constante por ousar empunhar um figurino que afinal só ratificava a impostura de sua pretensa elegância burguesa ${ }^{9}$. A roupa é para Eça mais que um índice usado na composição de suas personagens, ela é uma continuação do corpo e, como tal, um vigoroso argumento que diz aquilo que o narrador se furta em afirmar. Manuel Monforte, "o negreiro"10, perpassará toda a narrativa como uma sombra silenciosa. O passado que explica o seu enriquecimento é recuperado somente uma vez no livro, mas o mal-estar e o incômodo que o presente enriquecido e aburguesado lhe traz são descritosinsistentemente através da impostura de suas roupas, escolhidas pela filha no desejo de apagar os vestígios da origem do pai. As roupas são para Manuel Monforte não um sinal de melhoria, mas antes uma eterna acusação da qual não consegue escapar. No São Carlos: "o papá nunca lhe dava o braço: seguia atrás, entalado numa grande gravata branca de mordomo, parecendo mais tisnado e mais embarcadiço na claridade loira que saía da filha, encolhido e quase apavorado, trazendo nas mãos o óculo, o libreto, um saco de bombons, o leque e o seu próprio guarda-chuva" (QUEIRÓS, s/d 2 pp. 21-22). Incapaz de tornar a roupa uma segunda pele, Manuel Monforte padece da exclusão que se abate sobre toda sorte de párias, sobre todo aquele que não consegue copiar por ausência de recursos ou por simples incompetência - o estilo e a moda burgueses:

Com efeito, [a moda] é um dos instrumentos mais poderosos de integração e desempenha uma função niveladora importante, ao permitir que o indivíduo se confunda com o grupo e desapareça num todo maior que lhe dá apoio e segurança. E como as modas vigentes 
são sempre as da classe dominante, os grupos mais próximos estão, a cada momento, identificando-se aos imediatamente superiores através da imitação das vestimentas. (...) Essa mesma "democracia" que não estabelece barreiras nítidas entre as classes inventa um novo suplício de Tântalo, permite que as elites usufruam uma moda que a classe média persegue sem jamais alcançar e que os pequenos funcionários e todos os párias sociais espiam nas vitrinas com seu olhar sequioso. (SOUZA, 2005, pp. 130 e 141)

Mas não basta trajar o preto para ser um burguês modelar. Eusebiozinho desde a infância é marcado pelas cores escuras, sinais anunciadores da ave de rapina que a personagem se transforma quando adulto, deixando claro que, do interior ao exterior, Eusébio é um personagem em negro ${ }^{11}$. Cruges, o maestro tímido e misantropo, passa toda narrativa a reclamar dos sapatos que lhe apertam os pés ${ }^{12}$, ratificando a sua dificuldade de caminhar pelo tapete das etiquetas sociais. Alencar é propositalmente vestido para fora do tempo, guardando na falhada cabeleira branca e no vasto bigode um anacronismo que é puro romantismo ${ }^{13}$, romantismo este que será valorizado ao final do livro ${ }^{14}$, quando for visto como bem intencionado e legítimo se comparado aos modismos artificiais que povoam a Lisboa provinciana e carnavalizada da Regeneração:

Ega esfregava as mãos. Sim, mas precioso! Porque essa simples forma de botas explica todo o Portugal contemporâneo. Via-se por ali como a coisa era. Tendo abandonado o feitio antigo, à D. João VI, que tão bem lhe ficava, este desgraçado Portugal decidira arranjarse à moderna: mas, sem originalidade, sem força, sem carácter para criar um feitio seu, um feitio próprio, manda vir modelos do estrangeiro - modelos de idéia, de calças, de costumes, de leis, de arte, de cozinha... Somente, como lhe falta o sentimento da proporção, e ao mesmo tempo o domina a impaciência de parecer muito moderno e civilizado - exagera o modelo, deforma-o, estraga-o até a caricatura. O figurino da bota que veio de fora era levemente estreito na ponta - imediatamente o janota estica-o e aguça-o, até ao bico do alfinete. (QUEIRÓS, s/ $d_{2^{\prime}}$ p. 706)

Se a roupa é linguagem, uma bota deformada pode dizermuito de Portugal. Por isso, não faltam ao país recriado por Eça os tipos sociais que fizeram a história do século vitoriano. Lá está a multidão endomingada ${ }^{15}$; estão os pedintes esfarrapados a esperar pela esmola que redimia a culpa burguesa ${ }^{16}$; estão os criados vestidos a partir de uma cópia tacanha, cuja intenção era exaltar o poder aquisitivo de seus patrões ${ }^{17}$; estão os preceptores ${ }^{18}$ a reproduzir de maneira exagerada um comportamento inglês que punha em dúvida a excessiva espontaneidade portuguesa; bem como está a prostituta, como sempre espanhola, a 
mostrar provocativamente "o sapato de cetim, um pouco da meia de seda, lânguida e desdenhosa com um cãozinho no regaço" (QUEIRÓS, s/ $d_{2}$, p. 94).

As roupas em Eça podem definir nacionalidades, a "linha britânica" toma corpo no conde Steinbroken, "vestido como um inglês, inglês tradicional de estampa, com uma sobrecasaca justa de manga um pouco curta, e largas calças de xadrez sobre sapatões de tacão raso" (QUEIRÓS, $s / d_{2}$, p. 117); e são sinais caros do processo de aburguesamento pelo qual passou a sociedade portuguesa da Regeneração, bastando lembrar a melhoria sofrida pelas roupas do Vilaça, que termina a narrativa "calçando luvas amarelas. Estava mais gordo o Vilaça - e tudo na sua pessoa, desde o chapéu novo até ao castão de prata da bengala, revelava a sua importância como administrador" (QUEIRÓS, s/d 2 , p. 706). Aliás, as roupas são mesmo uma espécie de garantia de abundância e de prosperidade, haja vista a narração que Maria Eduarda faz de seu passado a Carlos, na tentativa de fazê-lo entender aquilo que o conforto da condição de herdeiro dos Maias o fazia incapaz de imaginar: a pobreza. Todos os percalços econômicos vividos por Maria Eduarda, por sua mãe e por sua filha estavam de perto atados à questão do vestuário, assim o frio que cortou seus corpos, as roupas que se desgastaram, aquelas que foram empenhadas junto com as joias - "levava ao prego embrulhos de roupas (até roupa branca, até camisas!)", (QUEIRÓS, s/d 2, p. 512) -, e o trabalho de costureira mal remunerado exercido por Maria Eduarda são sinais de uma miserabilidade inscrita na pele das roupas, de tal modo que a neta de Afonso não suporta se lembrar de Rosa vivendo em condições tão terríveis: "era um suplício vê-la perder as cores, tristinha, mal vestida, metida numa trapeira..." (QUEIRÓS, s/d 2, p. 514) ${ }^{19}$.

James Laver, ao falar da década de quarenta, é categórico ao afirmar que ela foi a época do apogeu da mulher-boneca, cuja tranquilidade e delicadeza eram as suas qualidades principais perante o mundo burguês: " de fato era chique ser, ou parecer um pouco souffrante, "saúde de ferro" era simplesmente vulgar. O ruge foi totalmente abandonado, uma 'palidez interessante' era admirada" (LAVER, 1996, p. 170). Tal descrição em nada fica a dever àquela que o narrador queirosiano faz de sua Raquel Cohen.

No entanto, não se pode perder de vista que entre o modelo histórico-social que a personagem encarna e o tempo ficcional em que ela vive existe uma defasagem de mais de 30 anos, o que de perto comprova o anacronismo de sua figura, característica estendível a todos os seus admiradores, inclusive ao moderníssimoEga, que parece não se importar com o passadismo que Raquel representa e que só deveria interessar ao seu utilitário marido-banqueiro. Raquel Cohen:

Era alta, muito pálida, sobretudo às luzes, delicada de saúde, com um quebranto nos olhos pisados, uma infinita languidez em toda a sua pessoa, um ar de romance e de lírio meio murcho, (...) Dizia-se que tinha literatura, e fazia frases. O seu sorriso lasso, pálido, constante, dava-lhe um ar de insignificância. O pobre Ega adorava-a. (QUEIRÓS, s/d 2 , p. 130)

Roland Barthes ao estudar o sistema da moda afirma que "é o duplo sonho que a retórica da Moda põe ao alcance da mulher: de identidade e 
de jogo" (BARTHES, 1979, p. 242). Sabendo jogar como ninguém, a condessa Gouvarinho parece não desperdiçar nada que a retórica da moda lhe pode fornecer, de maneira a assegurar que a sua imagem de fêmea fatal esteja garantida. Habilidosa jogadora, a Gouvarinho, de cabelos ruivos e com forte perfume de verbena, parece intuir que "quando a curiosidade sexual se contém sob o puritanismo dos costumes de uma sociedade burguesa, a moda descobrirá meios de, sem ofender a moral reinante, satisfazer um impulso reprimido" (SOUZA, 2005, p. 25). É claro que se a condessa leva a sério o seu papel de sedutora, o mesmo não acontece com o narrador que não dispensa a oportunidade de ridicularizar a frágil moral burguesa, criando uma cena de comédia pastelão ao narrar o primeiro beijo atrapalhado de Carlos e Gouvarinho. Seguindo um ritmo cômico, o narrador faz com suas personagens, literalmente, tropecem no excessivo aparato burguês e a roupa desmedida da condessa, de objeto de sedução, transforma-se num grande empecilho:

Mas a flor que ela the queira dar estava no boudoir, ao lado. Carlos seguiu a sua grande cauda, onde corria um reflexo dourado de folhagem de outono batida do sol. (...) A condessa escolheu um botão com duas folhas, e ela mesmo veio florir a sobrecasaca, Carlos sentia o seu aroma de verbena, o calor que subia do seu seio arfando com força. (...) E ela não acabava de prender a flor, com seus dedos trêmulos, lentos, que pareciam colar-se, deixar-se adormecer sobre o pano. (...) Carlos achou-se com os lábios nos lábios dela. A seda do vestido roçavalhe com um fino ruge-ruge entre os braços; - e ela pendia para trás a cabeça, branca como uma cera, com as pálpebras docemente cerradas. Ele deu um passo, tendoa assim enlaçada, e como morta; o seu joelho encontrou um sofá baixo, que rolou e fugiu. Com a cauda de seda enrolada nos pés, Carlos seguiu, tropeçando, o largo sofá, que rolou, fugiu ainda, até que esbarrou contra o pedestal onde o senhor conde erguia a fronte inspirada. E um longo suspiro morreu, num rumor de saias amarrotadas. (QUEIRÓS, s/d 2 , p. 297)

Mas se muito se fala das roupas e dos apetrechos de alguns personagens, outros carecem de melhor descrição. É de espantar que esta economia recaia justamente sobre os corpos de Pedro e de Afonso da Maia, elementos fulcrais para o desenvolvimento da narrativa. Para além dos olhos, dos cabelos e de um retrato num canto esquecido, muito pouco se sabe do aspecto físico de Pedro e dos objetos que o revestem. Enevoado pela presença sísmica de Maria Monforte, parece que desde o início Pedro estava condenado a ser uma lembrança difusa. No caso de Afonso, o silêncio narrativo pode ser explicado pela imutabilidade do personagem, afinal se há na narrativa um marco de seguridade e de fortaleza ele está fincado no corpo de Afonso da Maia. As poucas descrições que atentam para o que traja o avô repetem um discurso de simplicidade que foge à ostentação e que parece imune ao passar da moda. Afonso, com sua "coçada quinzena de veludilho" (QUEIRÓS, s/d 2 , p. 12) não cede às exigências burguesas, não precisando da roupa para 
garantir o seu lugar num mundo que the foi oferecido por suposto direito de nascimento.

Mas em matéria de moda masculina não há mesmo como competir com o vanguardismo de João da Ega. Se quiséssemos usar uma classificação contemporânea, Ega é o que poderíamos chamar de fashion, mas em linguagem oitocentista, o "terror de Celorico" é considerado um representante do dandismo em terras portuguesas. Segundo Michelle Perrot, o dandismo foi uma manifestação decorrente da atmosfera burguesa:

O dandismo representa uma forma ainda mais consciente e elaborada de recusa da vida burguesa (...), ele exacerba a diferença numa sociedade que tende à massificação. A boêmia se inclina para a esquerda, o dandismo se inclina para a direita. Antigualitário, ele gostaria de recriar uma aristocracia que certamente não seria a do dinheiro, ou da linhagem, mas a de um temperamento - "nasce-se" dândi - e de um estilo. (...) Ele alimenta o gosto da ilusão e do disfarce, tem um agudo senso dos detalhes e dos acessórios (luvas, gravatas, bengalas, echarpes, chapéus...). (PERROT, 1997, p. 297)

O Ega de Coimbra ou o da jovem maturidade vivida no Ramalhete é o que chamaríamos de iconoclasta, um herdeiro parasitário que ocupa seus dias preocupado em escandalizar por gestos, por discursos e por roupas, a "choldra" que para ele era Portugal. Ocupando seu tempo de ócio com medíocres casos de adultério, festas entediantes e jantares em que o nada é sempre o tema principal, Ega sobrevive perante os seus (e perante aos leitores) de seu inquestionável carisma: de fato, não há como não gostar de Ega. Mais do que qualquer personagem, o amigo de Carlos cedo descobriu que, numa sociedade aburguesada, o homem não vale tanto pelo o que tem, porque a imagem de sucesso só estará de fato garantida na consideração que seja capaz de despertar. Nesta consideração, "a riqueza é apenas um dos elementos, a família, a situação social" são outros aspectos de "participação na vida mundana (...) não menos importantes", porque, "um casamento brilhante ou a simpatia de uma coterie na moda modifica a favor [do indivíduo] o julgamento de opinião de todo o grupo" (SOUZA, 2005, p. 115). Por isso, Ega não poupará esforços para fazer da moda um instrumento de autopromoção: em Coimbra, "renovara as tradições da antiga boémia: trazia os rasgões da batina cosidos com linha branca" (QUEIRÓs, s/d, p. 92); em uma Lisboa acalorada e cheia de sol, já era "um Ega dandy, vistoso, paramentado, artificial e com pó de arroz", "trazia uma peliça, uma sumptuosa peliça de príncipe russo, agasalho de trenó e de neve, ampla, longa (...) pondo-lhe em torno do pescoço esganiçado e dos pulsos de tísico uma rica e fofa espessura de peles de marta" (QUEIRÓS, s/d 2 , p. 105). E como para Ega não há limite, ele chega a fantasiar-se de "Satanás pelintra" (QUEIRÓS, s/d 2 , p. 273), na tentativa de escandalizar o provinciano high lifelisboeta, o mesmo que metonicamente tentou tomar através do corpo adúltero de Raquel Cohen. Escandalizando os rígidos padrões da moda masculina, João da Ega nunca duvidou de que na era 
burguesa "a distinção econômica do luxo ced[ia] lugar à distinção estética da elegância" (SOUZA, 2005, p. 134). Ao voltar de seu exílio em Celorico por conta do escândalo de Raquel Cohen, Ega desabafa com Carlos:

Parou diante do grande espelho, deu um olhar descontente ao seu jaquetão claro e às botas com mau verniz. - Preciso enfarpelar-me de novo, Carlinhos... O Poole naturalmente mandou-te fato de Verão, hei-de querer examinar esses cortes da alta civilização... Não há negá-lo, diabo, esta minha linha está chinfrim! (QUEIRÓS, s/d 2 , p. 383)

Firmando-se como exemplaridade do padrão burguês, Carlos Eduardo, um eterno "príncipe da Renascença", encarna o modelo da elegância pautado na sobriedade, na contenção e no refinamento. Se, por um lado, as opções de cores, tecidos e cortes eram extremamente reduzidas no que diz respeito ao guarda-roupa masculino ${ }^{20}$, por outro, a elegância era ostentada através dos adereços e de certas atitudes que faziam a distinção entre aqueles que realmente tinham, daqueles que esforçadamente copiavam.

Tanto Carlos como Maria Eduarda são mais de uma vez flagrados "tomando banho", hábito higiênico experimentado somente por aqueles viviam sob o "preconceito do asseio, do linho imaculado, símbolo de que o seu portador não se empenha[va] em nenhuma espécie de trabalho manual" (SOUZA, 2005, p. 81). Do mesmo modo, a preocupação com as ditas roupas brancas ${ }^{21}$ persegue de perto os dois irmãos que desfrutam de uma aparência e de uma postura que denunciam a "herança das raças superiores" por eles compartilhada. Num inevitável determinismo, os corpos e as vestes de Carlos e de Maria Eduarda selam-lhes a tragicidade de um incesto esperado.

Pela sua figura, o seu luxo, ele destaca nesta cidade provinciana e pelintra. Ela, por seu lado, loira, alta, esplêndida, vestido pela Laferrière, flor de uma civilização superior, faz relevo nesta multidão de mulheres miudinhas e morenas. Na pequenez da Baixa e do Aterro, onde todos se acotovelam, os dois fatalmente se cruzam: e com o seu brilho pessoal, muito fatalmente se atraem! Há nada mais natural? Se ela fosse feia e trouxesse aos ombros uma confecção barata da Loja da América, se ele fosse um mocinho encolhido de chapéu-coco, nunca se notariam e seguiriam diversamente nos seus destinos diversos. Assim, o conhecerem-se era certo, o amaremse era provável... (QUEIRÓS, s/d 2 , p. 622)

Se a roupa masculina perece repetir um modelo que para Baudelaire era sinal luto, a vaidade do homem oitocentista vai aos poucos sendo deslocada para outros objetos, como é o caso dos chapéus, das bengalas, dos charutos ${ }^{22}$, das joias, das barbas e dos bigodes (e o de Carlos é virilmente destacado pela narrativa), igualmente presentes nas descrições que acompanham o neto de Afonso. Como ensina Gilda de Mello e Souza: 
É que a roupa masculina perdera, no século XIX, sua função ornamental, deixando de ser uma arma de sedução erótica. [o homem] não abandona outras formas mais sutis de afirmação social e prestígio, fixadas agora na exploração estética do rosto e no domínio de certas insígnias de poder e erotismo, como os chapéus, as bengalas, os charutos e as jóias. (...) o interesse pela decoração do rosto vem, pois, compensar o sacrifício do narcisismo masculino, que não se expressava na roupa, compensação que transparece, como já foi dito, no aumento dos símbolos fálicos da indumentária. (Souza, 2005, p. 75-76)

Para Carlos Eduardo, as roupas são como legendas sociais que ele, como ninguém, sabe ler com competência. Ao reconhecer, numa praça de Coimbra, o marido de sua amante, um rapaz "enxovalhado e macilento", "um pobre pai tão inofensivo no seu paletó coçado", Carlos decide romper o caso fortuito que até ali mantinha, por sentir-se "canalha em andar ali de cima do seu dog-cart, a preparar friamente" (QUEIRÓS, s/d 2 , p. 93) apenas por mero prazer - a "vergonha" de um casamento ordinário.

A destoante elegância de Carlos é apropriada somente à sua condição de herdeiro ocioso, por isso ele é um médico a quem ninguém é capaz de creditar uma intenção genuinamente produtiva, diz-lhe um colega: "Você é muito elegante para médico! (...) Quem é o burguês que the vai confiar a esposa dentro de uma alcova?... Você aterra o pater-famílias!" (QUEIRÓS, s/d 2 , p. 187). Sabendo do perigo que a linguagem das roupas pode causar, ao ser convidado para o baile dos Cohen, Carlos Eduardo recusa a fantasia de Francisco I, o Príncipe da Renascença, em favor de um discreto dominóz ${ }^{3}$, talvez intuindo a perigosa aproximação com Margarida de Navarra - fantasia escolhida por uma fogosa Gouvarinho - que ironicamente prevê o incesto que o futuro lhe reservava.

Carlos Eduardo é o produto de uma elite aburguesada, que costumou ver os pobres de forma estigmatizada. Não gratuitamente, ao ouvir Rosa pronunciar palavras pouco recomendáveis a uma menina de suposta condição social, o neto de Afonso corrige-lhe:

- Chinfrizitos.

Chinfrizitos! Quem lhe tinha ensinado a dizer uma coisa tão feia?

Rosa sorriu. Fora o Domingos. E o Domingos dizia ainda outras coisas assim, engraçadas... Dizia que a Melaine era uma gaja... O Domingos tinha muita graça.

Então Carlos advertiu-a que uma menina bonita, com tão bonitos vestidos, não devia dizer aquelas palavras... Assim falava a gente rota.

- O Domingos não anda roto - disse Rosa muito séria. (QUEIRÓS, s/d 2 , p. 404)

Como se vê, ser "roto" para Carlos é sinônimo de inferioridade cultural, de má educação e de caráter duvidoso, características avessas a uma menina "com tão bonitos vestidos"! A visão preconceituosa de Carlos 
Eduardo é dolorosamente percebida por Maria Eduarda que, em meio à briga em que revela o seu passado ao irmão, devolve a Carlos uma verdade que ele não era capaz de perceber:

- E eu? - exclamou ela, caminhando para ele, dominandoo, magnífica e com um esplendor de verdade na face. E eu? Porque hei-de eu acreditar nessa grande paixão que me juravas? O que é que tu amavas então em mim? Dize lá! Era a mulher de outro, o nome, o requinte do adultério, as toilettes?... Ou era eu própria, o meu corpo, a minha alma e o meu amor por ti?... (QUEIRÓS, s/d 2 p. 501)

Neste romance, as roupas não são apenas índices históricos ou sociológicos, elas também são instâncias psicológicas que acabam por denunciar forças inconscientes que se materializam através dos adereços e do vestuário. Maria Monforte será aquela que mais concretamente usará a roupa para dizer o indizível. Eça de Queirós, ao construir sua personagem, parece não ter poupado esforços para fazer significartudo aquilo que revestia ou que acompanhava seu corpo. Como outros escritores vitorianos, o autor de Os Maias acreditava que:

(...) é no elogio das roupagens que o impulso amoroso se desafoga. Talvez agora seja possível compreender melhor o interesse excessivo que a moda desperta nos escritores da época, o afã com que descrevem as cores, os tecidos, as jóias, os perfumes, enfim toda a ambiência mundana da mulher. A posse das roupagens, o acariciar com os olhos e as palavras, a máscara da vestimenta cingida muito rente ao corpo representavam, naquela época de severa vigilância, a única intimidade permitida. (SOUZA, 2005, p. 154)

Maria Monforte, um "modelo de Ticiano", parece nascida para seduzir: "quando ela atravessava o salão, os ombros vergavam-se no deslumbramento de auréola que vinha daquela magnífica criatura, arrastando com um passo de deusa a sua cauda de corte, sempre decotada como em noite de galas, e, apesar de solteira, resplandecente de jóias" (QUEIRÓS, s/d 2 , p. 23). Monforte fere a tolerância burguesa através do excesso. As numerosas jóias e, em particular, os sanguinários rubis, as camélias vermelhas que invariavelmente a acompanham, a indiscutível habilidade com os gestos - como saber "embrulhar-se com aquele gesto real o seu xale de Caxemira" (QUEIRÓs, s/d 2 , p. 25) -, os inúmeros "cartões de modistas" que guarda, a ousada "cigarrilha perfumada" que fuma "com os homens" nas festas do palacete de Arroios, a competência em insinuar-se diante de um público masculino paralisado por sua beleza, a arguta teatralidade (bastando lembrar o luto a que se forçou usar para parecer mais séria diante do marido traído), ou ainda, a sua sombrinha escarlate - que metaforicamente envolve Pedro "como uma larga mancha de sangue alastrado a caleche sob o verde triste das ramas" (QUEIRÓS, s/d 2 , p. 30) - são sinais que fazem de Maria Monforte 
o exemplo mais bem acabado do perigo da sedução feminina ${ }^{24}$. "Soberbamente bela sob as roupagens clássicas de Helena ou no luxo sombrio do luto oriental de Judite" (QUEIRÓS, s/d 2 , p, 36), Maria Monforte está vestida para mataro decoro burguês, através de uma luminosidade que fere a sombria moda vitoriana:

Nunca Maria Monforte aparecera mais bela: tinha uma dessas toilettes excessivas e teatrais que ofendiam Lisboa, e faziam dizer às senhoras que ela se vestia "como uma cômica". Estava de seda cor de trigo, com duas rosas amarelas e uma espiga nas tranças, opalas sobre o colo e nos braços; e estes tons de seara madura batida do sol, fundindo-se com o ouro dos cabelos, iluminando-lhe a carnação ebúrnea, banhando as suas formas de estátua, davam-lhe o esplendor de uma Ceres. (QUEIRÓS, s/d 2 , p. 26)

Resta Maria Eduarda e quem sabe só ela merecesse este ensaio. Poucas personagens despertaram em seu criador a fascinação que a neta de Afonso foi capaz de despertar. Muitas vezes acusado de ser um autor misógino, pouco chegado ao universo feminino, incapaz de criar mulheres de papel que ficassem para a história literária como ficaram Capitu, Bovary ou Karenina, Eça parece dispensar especial atenção à fulgurante aparição de Maria Eduarda, dedicando-lhe preciosas descrições que confirmam a impressão de Carlos ao vê-la pela primeira vez: trata-se de uma "deusa".

Ao contrário das demais personagens femininas, Maria Eduarda está apartada de qualquer forma de exagero, suas roupas marcam-se pela sobriedade e pela elegância, quase sempre assinaladas pelo preto e pelo branco. A racionalidade, a inteligência, o utilitarismo producente, o bom gosto e o equilíbrio são sinais de sua personalidade materializados em seu vestuário, aliás qualidades muito mais viris do que gostaria a sociedade oitocentista que a cercava. Chama atenção o número de vezes em que as roupas da neta de Afonso são descritas como simples, retas e de cores escuras, qualidades que recusam o exagero a que estavam submetidos os corpos femininos, ao mesmo tempo em que dão à sua dona uma humanidade e uma simplicidade que rejeitam o etéreo lugar de deusa destinado a ela pelos olhos apaixonados de Carlos (e também pelos do narrador):

Mas não escutava, nem sorria já. Do fim do Aterro aproximava-se, caminhando depressa, uma senhora que ele reconheceu logo, por esse andar que lhe parecia de uma deusa pisando a Terra, pela cadelinha cor de prata que lhe trotava junto às saias, e por aquele corpo maravilhoso onde vibrava, sob linhas ricas de mármore antigo, uma graça quente, ondeante e nervosa. Vinha toda vestida de escuro numa toilette de serge muito simples que era como o complemento natural de sua pessoa, colando-se sobre ela, dando-lhe, na sua correcção, um ar casto e forte; trazia na mão um guarda- 
sol inglês, apertado e fino como uma cana; e toda ela, adiantando-se assim no luminoso da tarde, tinha, naquele cais triste de cidade antiquada, um destaque estrangeiro, como o requinte claro de civilizações superiores. Nenhum véu, nessa tarde, lhe assombreava o rosto. (...) Sim, era bem uma deusa. Sob o chapéu, numa forma de trança enrolada, aparecia o tom de seu cabelo castanho, quase loiro à luz; a cadelinha trotava ao lado, com as orelhas direitas. (QUEIRÓs, s/d 2 , p. 202-203)

Maria Eduarda foi criada para iluminar e o narrador torna isto claro desde sua primeira "aparição": "num passo soberano de deusa", ela deixa "atrás de si como uma claridade, um reflexo de cabelos de oiro, e um aroma no ar" (QUEIRÓS, s/d 2 , p. 157). A partir de então, a luminosidade que a cerca, o doirado dos cabelos e a brancura de sua pele caminharão lado a lado, rompendo as sombras que envolvem a fatalidade de seus passos. Muitas são as vezes em que a descrição dos aspectos físicos ganha qualidade sinestésica. Mais do que para serem vistas, as imagens são construídas para serem sentidase as roupas da ficção, além de cobrirem o corpo das personagens, também vestem os olhos do leitor. Por isso a textura das rendas que envolve o corpo de Maria Eduarda é tão importante ${ }^{25}$, por isso as cores escuras das roupas são molduras eróticas para uma pele branca descrita como "de mármore"26, e também por isso, o perfume de jasmim é uma extensão aromática do corpo feminino tão desejado por Carlos: "pelo corredor amarelo, caminhando ao seu lado, Carlos perturbava-se sentindo a carícia, desse íntimo perfume em que havia jasmim, e que parecia sair do movimento das suas saias" (QUEIRÓS, $s / d_{2}$, p. 366). O que Carlos Eduardo não conseguia racionalmente explicar era que:

O perfume cumpre a mesma missão por meio do olfato, que o adorno por meio da vista. E esta irradiação do corpo feminino atinge os vários sentidos do homem, aprisionando-o em sua atmosfera. É que as barreiras, derivadas de uma moral estreita, impedindo a admiração estética do corpo nu, deslocavam em grande parte o interesse para o invólucro do corpo, e a avaliação dos valores eróticos baseava-se tanto nas modas de vestimenta quanto na apreciação da beleza física. (SOUZA, 2005, p. 152)

Uma das cenas mais sensuais do livro é protagonizada por Carlos e as roupas de Maria Eduarda. Ao visitar pela primeira vez os aposentos da irmã durante sua ausência, Carlos penetra na intimidade de uma mulher há muito desejada. Tal qual um amante devotado, ele percorre o desenho das roupas, a forma dos objetos pessoais como quem, metonimicamente, toma posse de um corpo construído por sua imaginação desejante, contando, para isto, com o apoio de um narrador que parece não poupar esforços numa descrição marcadamente erotizada. Vale à pena a longa transcrição: 
Carlos ficou só, na intimidade daquele gabinete de toilette, que nessa manhã ainda não fora arrumado. Duas malas, pertencentes decerto a madame, enormes, magníficas, com fecharias e cantos de aço polido, estavam abertas: de uma transbordava uma cauda rica, de seda forte cor de vinho: e na outra era um delicado alvejar de roupa branca, todo um luxo secreto e raro de rendas e baptistes, de um brilho de neve, macio pelo uso e cheirando bem. Sobre uma cadeira alastrava-se um monte de meias de seda, de todos os tons, unidas, bordadas, abertas em renda, e tão leves que uma aragem as faria voar; e no chão corria uma fila de sapatinhos de verniz, todos do mesmo estilo, longos, com o tacão baixo, e grandes fitas de laçar. (...) Mas o olhar de Carlos prendiase sobretudo a um sofá onde ficara estendido, com duas mangas abertas, à maneira de dois braços que se oferecem, o casaco branco de veludo lavrado de Génova como ele a vira, a primeira vez, apear-se à porta do hotel. O forro, de cetim branco, não tinha o menor acolchoado, tão perfeito devia ser o corpo que vestia: e assim, deitado sobre o sofá, nessa atitude viva, num desabotoado de seminudez, adiantando em vago relevo o cheio de dois seios, com os braços alargando-se, dando-se todos, aquele estofo parecia exalar um calor humano, e punha ali a forma de um corpo amoroso, desfalecendo num silêncio de alcova. Carlos sentiu bater no coração. Um perfume indefinido e forte de jasmim, de marechala, de tanglewoodelevava-se de todas aquelas coisas íntimas, passava-lhe pela face como um bafo suave de carícia... (QUEIRÓS, s/d 2 , pp. 260-261)

Uma pulsão erótica como esta não poderia sobreviver dentro do universo aburguesado a que os irmãos da Maia pertenciam. Não gratuitamente, o romance termina com uma Maria Eduarda enlutada, partindo de Lisboa em silêncio e na direção de um exílio que não foi decisão sua: "vinha toda envolta numa grande peliça escura, com véu dobrado, espesso como uma máscara", "grande, muda, toda negra na claridade, à portinhola daquele vagão que para sempre a levava" (QUEIRÓS, s/d 2 , pp. 686-687). Mas a narrativa presta a ela e a Afonso da Maia a sua derradeira homenagem. De volta a um Ramalhete abandonado, depois de uma ausência de mais de dez anos, João da Ega encontra entre as ruínas do antigo palacete:

(...) uma caixa de chapéu sem tampa, atulhada de coisas velhas - um véu, luvas desirmanadas, uma meia de seda, fitas, flores artificiais. Eram objectos de Maria, achados nalgum canto da Toca, para ali atirados, no momento de se esvaziar a casa! E, coisa lamentável, entre estes restos dela, misturados como na promiscuidade de um lixo, aparecia uma chinela de veludo bordada a matiz, uma velha chinela de Afonso da Maia. (QUEIRÓs, s/d2, p. 708) 
Se as roupas são linguagem, o véu, as luvas, a meia de seda, as fitas e as flores artificiais de Maria Eduarda misturadas à chinela de veludo bordada de Afonso soam como uma triste e afetuosa metáfora, que primeiro restitui à neta uma família prematuramente roubada, para depois fazer com que Maria Eduarda e Afonso permaneçam como legítima ruína de uma história que sobreviveu abrigada por uma casa-memória: para ambos, merecida herança.

\section{REFERÊNCIAS BIBLIOGRÁFICAS}

ABRANTES, Samuel. "Erté e a representação estética do feminino ambivalência, rasura e descontinuidade". In: COUTINHO, Luiz Edmundo Bouças \& CORRÊA, Irineu E. Jones. (orgs.). O Labirinto finessecular e as idéias do esteta (ensaios críticos). Rio de Janeiro: Faculdade de Letras/UFRJ/7Letras, 2004, pp. 106-117.

BARTHES, Roland. Aula. São Paulo: Cultrix, 1980. . Mitologias. Rio de Janeiro: Bertrand do Brasil, 1993.

. Sistema da moda. São Paulo: Companhia Editora Nacional/Editora da Universidade de São Paulo, 1979.

GAY, Peter. A experiência burguesa da Rainha Vitória a Freud. Guerras do Prazer, vol. 5. São Paulo: Companhia das Letras, 2001.

GOLDENBERG, Mirian (org.). Nu \& Vestido. Dez antropólogos revelam a cultura do corpo carioca. Rio de Janeiro: Editora Record, 2002.

LAVER, James. A roupa e a moda. Uma história concisa. São Paulo: Companhia das Letras, 1996.

PERROT, Michelle (org.). História da vida privada. 4. Da Revolução Francesa à Primeira Guerra. São Paulo: Companhia das Letras, 1997.

QUEIRÓS, Eça de. Correspondência. Lisboa: Livros do Brasil, s/d 1 . Os Maias. Lisboa: Livros do Brasil, s/d 2 .

Textos de imprensa. V (da Revista moderna), Ed. Elena Losada Soler. Lisboa: Imprensa Nacional-Casa da Moeda, 2005, p. 62.

ROCHE, Daniel. História das coisas banais. Nascimento do consumo nas sociedades do século XVII ao XIX. Rio de Janeiro: Editora Rocco, 2000.

SCHMITT, Juliana. Mortes vitorianas. Corpos, luto e vestuário. São Paulo: Alameda, 2010.

SOUZA, Gilda de Mello e. O espírito das roupas. A moda no século dezenove. São Paulo: Companhia das Letras, 2005.

\section{NOTAS}

1. Em carta a Oliveira Martins, datada de 10 de Maio de 1884, Eça de Queirós escrevia: "Eu continuo com Os Maias, essa vasta machine, com proporções enfadonhamente monumentais de pintura a fresco, toda trabalhada em tons pardos, pomposa e vã, e que me há-de talvez valer o nome de Miguel Ângelo da sensaboria." (QUEIRÓs, s/d 1 , p. 56)

2. Segundo James Laver: "as grandes civilizações antigas surgiram nos vales férteis do Eufrates, do Nilo e do Indo, ou seja, em regiões tropicais onde a proteção contra o frio não pode ter sido o principal motivo para se usar roupas. Muitos desses motivos foram relatados, abrangendo desde a idéia ingênua, baseada no relato do Gênesis, de que o uso das roupas deveu-se ao pudor. Até a noção sofisticada de que eram usadas por motivos de exibição e mágica protetora." (LAVER, 1996, p. 7) 3. Michelle Perrot mostra a importância concedida a este novo objeto de desejo das mulheres das classes médias: "Gradualmente, sobretudo no último terço do século XIX, o trabalho domiciliar, no âmbito de uma indústria de confecção dividida e 
racionalizada, canaliza essa imensa força de trabalho das mulheres em casa. As primeiras seduções da máquina de costura - ter sua Singer passa a ser o sonho de muitas donas de casa - levam-na a se confinar em casa, numa ruptura total com seus hábitos de andar pela cidade." (PERROT, 1997, p.144)

4. Peter Gay aponta para o quanto a "popularização" do vestir se tornou possível através do incremento do recente comércio varejista, que se utilizava da promessa de refinamento para elevar as suas vendas: "Os vendedores que trabalhavam em lojas de departamento francesas e alemãs, provenientes geralmente da classe trabalhadora, eram admitidos nas camadas inferiores da burguesia, quando seus superiores lhes ensinavam como vestir-se e como tratar os clientes. (...) escapar do mundo da classe trabalhadora conseguindo um emprego num escritório ou numa loja de departamentos era um momento de real libertação. As fantasias inebriantes sobre as roupas e entretenimento tornavam-se desejos realistas." (GAY, 2001, p. 23) 5. A chamada escola dos Annales, fundada por Lucien Febvre e Marc Bloch em 1929, é um movimento historiográfico que se constitui em torno do periódico acadêmico francês Annales d'histoire économique et sociale, tendo se destacado por incorporar métodos das Ciências Sociais à História.

6. Não se pode perder de vista que "em um contexto social e histórico particularmente instável e mutante, no qual os meios tradicionais de produção de identidade - a família, a religião, a política, o trabalho, entre outros - se encontram enfraquecidos, é possível imaginar que muitos indivíduos ou grupos estejam se apropriando do corpo como um meio de expressão (ou de representação) do eu." (GOLDENBERG, 2002, p. 21).

7. Segundo Roland Barthes: "(...) o poder está presente nos mais finos mecanismos do intercâmbio social: não somente no Estado, nas classes, nos grupos, mas ainda nas modas, nas opiniões correntes, nos espetáculos, nos jogos, nos esportes, nas informações, nas relações familiares e privadas, e até mesmo nos impulsos libertadores que tentam contestá-lo (...) Plural no espaço social, o poder é, simetricamente, perpétuo no tempo histórico: expulso, extenuado aqui, ele reaparece ali; nunca perece; façam a revolução para destruí-lo, ele vai imediatamente reviver, re-germinar no novo estado de coisas. (...) A razão dessa resistência e dessa ubiqüidade é que o poder é parasita de um organismo trans-social, ligado à historia inteira do homem, e não somente à sua história política, histórica. Esse objeto em que se inscreve o poder, desde toda a eternidade humana, é: a linguagem - ou, para ser mais preciso, sua expressão obrigatória: a língua." (BARTHES, 1980, pp. 11-12) 8. Sobre a crinolina, explica James Laver: "um dos princípios da moda parece ser o de que, uma vez aceito o exagero, ele se torna cada vez maior. Assim, no final da década, as saias armadas pelas crinolinas eram verdadeiramente prodigiosas, ao ponto de tornar impossível que duas mulheres entrassem juntas em uma sala ou sentassem no mesmo sofá porque os babados dos vestidos ocupavam todo o espaço. A mulher era um navio majestoso navegando orgulhosamente na frente, enquanto um pequeno escaler - seu acompanhante masculino - navegava atrás." (LAVER, 1996, p. 180)

9. Transcrevo a recepção dada à roupa de Dâmaso pelo dito high life. "Eu ainda hoje não pude cavaquear com o high lifel... Mas estou furioso, sabes? Implicaram com o meu véu azul. Isto é um país de bestas! Logo troça, e olhe que não creste a pele, e onde mora, ó catitinha? E chalaça... Uma Canalha! Tive de tirar o véu... Mas já resolvi. Para as outras corridas venho nu! Palavra, venho nu! Isto é a vergonha da civilização, esta terra!" (s/d 2, pp. 337-338)

10. Cito: "O papá Monforte era dos Açores: muito moço, uma facada numa rixa, um cadáver a uma esquina tinham-no forçado a fugir a bordo de um brigue americano. (...) Enfim, quando reapareceu à face dos céus, comandava o brigue "Nova Linda", e levava cargas de pretos para o Brasil, para Havana e para a Nova Orleães. Escapara aos cruzeiros ingleses, arrancara uma fortuna da pele do africano, e agora rico, homem de bem, proprietário, ia ouvir a Corelli a S. Carlos." (s/d 2 , pp. 24-25)

11. Cito: "(...) o Eusebiozinho de Santa Olávia estendia também o pescoço, afogado numa gravata de viúvo, de merino negro e sem colarinho, sempre macambúzio, mais molengo que outrora, com as mãos enterradas nos bolsos - tão fúnebre que tudo nele parecia complemento de luto pesado, até o preto do cabelo chato, até o preto das lunetas de fumo." (s/d 2 , p. 117)

12. Cito: "(...) Enquanto Carlos, batendo no joelho do maestro, queria saber como ele se portara naquele lance de honra... - Pessimamente! - gritou Ega! - Com expressões 
de compaixão, sem linha nenhuma; estendido por cima do piano; agarrando com a mão no sapato... - Pudera! exclamou Cruges desafogado enfim, - Vocês dizem-me que me ponha de cerimônia, calço uns sapatos novos de verniz, estive toda a tarde num tormento! E não se conteve mais, arrancou o sapato, pálido, com um medonho suspiro de consolação." (s/d, pp. 562-563)

13. Cito: "E apareceu um indivíduo muito alto, todo abotoado numa sobrecasaca preta, com uma face escaveirada, olhos encovados, e sob o nariz aquilino, longos, espessos, românticos bigodes grisalhos: já todo calvo na frente, os anéis fofos de uma grenha muito seca caiam-lhe inspiradamente sobre a gola: e em toda a sua pessoa havia alguma coisa de antiquado, de artificial e de lúgubre." (s/d 2, p. 159)

14. Cito: "Mas Carlos agora também contemplava o Alencar. E parecia-lhe mais bonito, mais poético, com sua grenha inspirada e toda branca, e aquelas rugas fundas na face morena, cavadas como sulcos de carros pela tumultuosa passagem das emoções... - Estás típico, Alencar! Estás a preceito para a gravura e para a estátua..." $\left(s / d_{2}\right.$, p. 692)

15. Michele Perrot ensina que "o operário pretende vestir-se à burguesa para fazer sua festa mesclado com a multidão urbana. O repouso dominical reveste-se a partir daí de um novo significado. Endomingar-se é mostrar-se sensível à moral da limpeza." (PERROT, 1997, p. 449)

16. Daniel Roche adverte que dentro da sociedade burguesa "o luxo podia assim se transformar em caridade", afinal, "no mercado dos bens espirituais, o supérfluo se convertia em riqueza espiritual para o doador, em bens necessários para os pobres assistidos." (ROCHE, 2000, p. 104)

17. Quando Carlos vai à casa de Dâmaso, o narrador faz questão de destacar através do recurso dos parênteses, a incoerência dos trajes do criado que atende ao visitante: "Carlos, sinceramente inquieto, julgando-o moribundo, foi uma manhã a casa dele, à Lapa. Mas aí, o criado (um galego achavascado e triste, que, desde as suas relações com os Maias, Dâmaso trazia entalado numa casaca e mortalmente aperreado em sapatos de verniz) afirmou-lhe que o sr. Damasozinho estava de boa saúde, e até saíra a cavalo." (s/d 2, p. 201)

18. Cabe destacar a presença do Sr. Brown, "solidamente abotoado na sua longa sobrecasaca militar, (...) rígido e teso" (s/d 2, p. 60); e de Miss Sara, "séria e recolhida - sempre de preto, com uma ferradura de prata em broche sobre o colarinho de homem (...) [era] gordinha, com o peito de pomba farta estalando dentro do corpete severo" (s/d 2, pp. 454-455), ambos donos de uma artificial inflexibilidade que, da postura à roupa, não combina com a sinuosa sociedade lisboeta.

19. Não se deve perder de vista que a vida "confortável" que Maria Eduarda tem ao lado de Castro Gomes aparece refletida não só numa Rosa ricamente trajada, mas também em suas bonecas. Reclamando com a mãe que havia perdido o robe-dechambre da boneca Crici, a menina recebe da mãe a seguinte : "-Vejam esta desarranjada! - murmurava a mãe, olhando-a com um sorriso lento e terno. - Se Cricri tem uma cômoda particular, o seu guarda-vestidos, não se lhe deviam perder as coisas... Pois não é verdade, sr. Carlos da Maia?" ( $s / d_{2}$, p. 354)

20. Gilda de Mello e Souza explica as causas históricas desta contenção: "o homem se desinteressou da vestimenta quando esta, devido à mudança profunda no curso da história, deixou de ter importância excessiva na competição social. A Revolução Francesa, consagrando a passagem de uma sociedade estamental a uma sociedade de classes, e estabelecendo a igualdade política entre os homens, fez com que as distinções não se expressassem mais pelos sinais exteriores da roupa, mas através das qualidades de cada um." (SOUZA, 2005, p. 80)

21. Historicamente, Daniel Roche explica o desenvolvimento das roupas brancas: "Era o dilema principal da invenção da roupa de baixo. Ela era a portadora da nova higiene moral e social porque a seco ela absorvia o suor, fazia paravento contra a sujeira íntima, protegia o corpo das doenças, mas ao mesmo tempo multiplicava as exigências da limpeza, sob pena de perder a eficiência. Cuidados e limpeza não marchavam no mesmo ritmo para o corpo e para a roupa de baixo que, no mesmo momento, atraía a atenção de uma nova epidemiologia." (ROCHE, 2000, p. 215)

22. Segundo Gilda de Mello e Souza: "O hábito dos charutos que, difundido a partir de meados do século, atravessa o Romantismo, banindo a um só tempo o vício antigo do rapé, a que continuam fiéis os mais velhos, e o nojento cigarro de palha a que estão condenados os mais pobres. Pois o moço bonito (...) fuma charutos de 
primeira qualidade, Havana ou de Manilha, (...) estão sempre ao alcance da mão sobre a escrivaninha ou o aparador, na intimidade dos aposentos." (SOUZA, 2005, p. 78-79)

23. A fantasia de dominó, de influência francesa, consiste em túnica longa e leve, de amplas mangas e capuz, freqüentemente na cor negra, muito usada em bailes de máscaras europeus. Em geral o tecido empregado na confecção dessas fantasias era o cetim, tipo de seda lustrosa e macia, recortada em losangos, que também poderiam ser bicolores.

24. A criação de uma existência feminina pautada na sedução pode ser explicada historicamente: "tendo a moda como único meio lícito de expressão, a mulher atirouse à descoberta de sua individualidade, inquieta, a cada momento insatisfeita, refazendo por si o próprio corpo (...) procurou em si - já que não lhe sobrava outro recurso - a busca de seu ser, a pesquisa atenta de sua alma. E aos poucos, como o artista que não se submete à natureza, impôs à figura real uma forma fictícia, reunindo os traços esparsos numa concordância necessária. (SOUZA, 2005, p. 100)

25. Sobre a mensagem subliminar que as rendas incorporam, Juliana Schmitt afirma: "iniciou-se assim a tendência de se deixar à mostra golas e punhos candidamente brancos e ricamente adornados com renda e babados e vazados. Ele [o branco] é uma testemunha do "por baixo". É o oculto que se mostra. Ele revela o que o traje cobre. O branco, nesse caso, indica uma limpeza particular: a do interior. A roupa branca era representante da pele." (SCHMITT, 2010, p. 39)

26. Cito: "[Maria Eduarda] Ela, com um vestido simples e justo de sarja preta, um colarinho direito de homem, um botão de rosa e duas folhas verdes no peito, alta e branca, sentou-se logo junto da mesa oval, acabando de desdobrar um pequeno lenço de renda. (...) E através da manga justa de sarja, terminando num punho branco, ele sentia a beleza, a brancura, o macio, quase o calor de seus braços." (s/d 2 , pp. 343-344) 